\title{
Protecting Families: A Qualitative Study on the Implementation of Protective Measures to Prevent COVID-19 Transmission
}

\author{
Ni Komang Ari Sawitri ${ }^{1 *}$ (D), Indah Mei Rahajeng ${ }^{1}$, Luh Putu Eva Yanti ${ }^{1}$, Ida Ayu Agung Novi Jayanti ${ }^{2}$ \\ ${ }^{1}$ Nursing Study Program, Faculty of Medicine, Udayana University, Kuta Selatan, Indonesia; ${ }^{2}$ Southern Denpasar Community \\ Health Centre, Denpasar, Indonesia
}

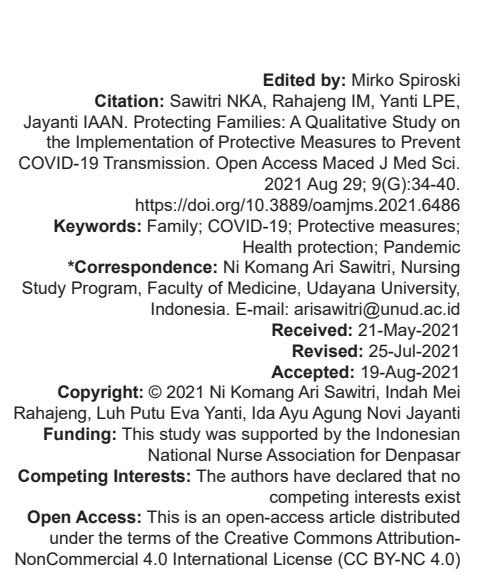

\section{Introduction}

Families are important units in society in the context of health promotion, disease prevention, and adoption of health behaviors [1]. During the COVID-19 pandemic, families are also expected to continue their participation in preventing the spread of COVID-19. In Indonesia cases of COVID-19 continue to increase. The latest data shows that the national number of cases is more than 200,000; the number of cases being treated is more than 51,000 ; the number of recovered patients is more than 147,000; and the number of deaths from COVID-19 has reached more than 8000 people [2]. The number of cases in Bali also continues to increase, with Denpasar being the hardest hit [3]. The Indonesian government has begun to ease Large-Scale Social Restrictions since early June 2020, hoping people would be accustomed to the "new normal" reality.

In the new normal, people are expected to continue carrying out activities but must always implement protective measures [4] —including wearing masks in public places; maintaining a distance of 1.5-2 m; avoiding gathering and crowded places; practicing protective behaviors when using public transportation, when coming home, when shopping, and working at offices [4]. The application of the new normal as well as habits for the prevention of other diseases requires high awareness and continuous education [5]. In the new normal, the task force for Handling COVID-19 continues to educate the public by emphasizing the role of families in the implementation of protective measures. In any situations, families are indeed the basic units that become critical success factors in promoting individuals' and communities' health, as well as in public health policy-making [6]. Family-oriented health promotion is often considered a promising intervention in a disease prevention process [7]. However, families as a system is overly complex and each member influences and is influenced by each other [8]. This creates various dynamics that will affect health behavior practices and the individuals' health [9]. Considering the complexity and the probability of the current pandemic to stay for a long term, a study is needed to explore the implementation of protective measures among families. This study is a part of the bigger study on familial experiences in implementing protective measures in Denpasar. The result of the current study is expected to inform the planning of interventions by policy makers as research 
on the implementation of protective measures in the new normal period in Denpasar City is lacking, if not nonexistence.

When this study was conducted the vaccines were still on a trial stage, and the efforts that could be done to minimize the spread of COVID-19 were through strict implementation of protective measures. This is particularly important because, with the relaxation of Large-Scale Social Restrictions, communities have begun to gather in public spaces, which increases the risk of virus transmission. Additionally, misleading news and influences on various media may lead people to undermine the importance of protective measures; for example, the term "new normal" is often considered normal, which may reduce compliance with health protocols [10]. Meanwhile, the number of cases in Denpasar continues to increase to date, with Denpasar being the epicenter [3]. Even though the vaccines have been gradually distributed, asymptomatic vaccinated individuals can still spread the virus [11]. Therefore, protective measures remain a preferable option to reduce the spread. Research on the responses at the household level would be valuable as a point of reference for the improvement of COVID-19 prevention programs.

\section{Methods}

The aim of this study is to gain understanding of the complexity and uniqueness of the implementation of protective measures among families in Denpasar. This study is qualitative in nature, which breaks down the complex, distinctive family experiences [12], [13]. Basic qualitative research [14] becomes the basis of the analysis to identify themes arising from the data.

Participants of this study are family members who reside in Denpasar for the last 6 months, aged 10-60 years, and reachable via landline or mobile phone. We excluded family members who were assigned as COVID-19 volunteers, those who work as healthcare professionals, and those who have health education background. Eighteen families consist of 30 individuals participated in this study. They were invited from 11 Puskesmas (Community Health Centre) in Denpasar. Most participants preferred to be called via WhatsApp, and some preferred conversation through phone call, and there were some who preferred to answer questions through messages on WhatsApp. The interviews were conducted via phone because it was not possible to meet the participants in person due to the current pandemic situation. Phone interviews is an alternative way of collecting data, when in-person interviews cannot be carried out [15]. Besides, such interviews have the perk of not having to disturb family activities [16]. To complement phone interviews, we also collected data via text messages because the answers given by participants could be more precise and informative [17].

Semi-structured interviews were conducted using interview guides that have been discussed with the research team, and pre-tested. Eight questions given to the participants were about COVID-19; new normal; protective measures and its implementation at family setting and neighborhood; the challenges; and their opinion on public policies. Phone call interviews were recorded with a voice recorder with a duration of 10-44 min, and the interviewer also made notes to highlight important information. The recording was transcribed verbatim and mainly analyzed by the main researcher, assisted by the other researchers. An application called Dedoose is used to assist in data management during the data analysis process [18]. Six steps thematic analysis by Braun [19] was conducted.

This study has obtained ethical approval from the Ethics Committee of Faculty of Medicine Udayana University and Sanglah Hospital. Pseudonyms were assigned toall participants and autonomy was maintained by keeping participation voluntary [20], [21], [22]. This study applies two criteria to ensure that the research results are reliable, namely by making a research diary and by triangulating the data analysis process [23]. This research applies analyst triangulation to ensure credibility [24] by employing three other researchers (aside from the main researcher) to carry out the data analysis, then the results of each analysis were compared. Researchers also kept research diaries trough out the entire process.

\section{Results}

The analyses show that there were five themes identified from the data. The families involved in this study were fully aware of the importance of implementing protective measures to protect family members' health. However, the implementation of the measures was very irregular. Each theme in the following section describes the dynamic of protective measures implementation within the family.

\section{Theme 1: Fundamental concerns}

Implementing protective measures has become a fundamental concern of every family in everyday life during the pandemic. While certain protective measures are non-negotiable, there are also additional protocols that families implement to reduce the risk even further. The two mandatory measures are wearing masks and washing hands. 
"If you leave the house, of course, you wear a mask, then wash your hands. Use hand sanitizer, if you go out shopping, after holding banknotes, after handling the groceries we must use hand sanitizer-something like that." (Raditya)

Families also carried out other protective measures besides the wearing masks and using hand sanitizer; for example, not sharing cutleries and improving the immune system.

"Eh... now since COVID we have our own cutleries, so in the past, eh could share [cutleries] right?" (Kirana)

"Sometimes we exercise and then sunbathe, then take vitamins." (Ayudia)

\section{Theme 2: Restraints and constraints}

This theme illustrates how families must change their daily routines due to the Large-Scale Social Restrictions, and the difficulties in implementing protective measures. The containment measures required family members to do all activities, i.e. work, school, and socializing from home. Most respondents expressed their fear of contracting COVID-19 so they adhere the requirement of staying at home.

"Eh, I am a bit parno [paranoid] to be honest, so I kind of find a place of refuge at home. I [stay] in the house most of the times. There is absolutely no going out of the house at all times, especially for the children, I forbid them playing outside." (Kirana)

Respondents also reported that the most challenging protective measures for families to implement was keeping a safe distance, especially in public spaces whenever they have to leave the house, such as when going to traditional markets.

"The most difficult thing is like gathering eh... don't get together... but for example, if we go to a public place, people will still be together, ma'am. If we go to the market. like we go to the market..." (Ratna)

Some respondents believe that lack of awareness could be the reason why people do not strictly adhere to the rules:

"But yes, there are also many [people] outsides [who are] still ignorant, right? We are the ones who keep the distance, but those who are careless, you know..." (Rocky)

The respondents realize that restrictions are made to protect themselves and others, and they try their best to adhere to it but there are externalities that thy could not control. Lack of awareness of other people was perceived as a hindrance to implement protective measures properly.

\section{Theme 3: The pandemic roles}

During the pandemic, there have been substantial changes in the way family members live, work and carrying out daily activities. To navigate the changes, families seem to have developed informal roles assigned specifically to each member. These roles are mainly to facilitate the protective measures implementation; and consist of a reminder, a supplier and an information seeker. First, the job of a reminder to remain others to keep complying with the protective measures.

"Eh... for me, all... all my family members remind each other; for example, when we leave the house, and then we come back, we have to wash our hands, ma'am. We remind each other." (Harry)

As for a supplier, the job is to ensure that the family has enough supply of equipment so family members will be able to change masks and wash their hand properly. It is often the women who take the supplier role.

"The masks are three layers of surgical masks... uh huh... I usually stock [them] at home." (Andina)

The role of information seeker is taken by almost all family members, with the information sought being cases updates, protective measures and policies. To some extent, the pandemic has brought to the forefront the importance of information literacy. Since the beginning of the outbreak, families have subscribed to various sources of information. They search for information to find out what one must do to prevent virus transmission, to treat oneself or family member in case of infection, and to anticipate the impacts of the pandemic in general.

"About eh, this information is usually about public places that are safe if I ... because [we are] already tired [of staying at home]." (Jeny) "Umm. maybe the information [I] look for again. how can I... overcome that so that we don't get infected, well, just like reduce the number... the death rate because of that virus." (Sekar)

\section{Theme 4: Compromising}

Families have implemented protective measures to the best of their abilities since the outbreak of COVID-19. However, there were times when they had to compromise the protective measures because of certain conditions.

"To keep the distance, I don't think there is [keeping distance]; for example, we want to tell people not to go out, we can't do that either because everyone has their own autonomy like eh; for example, in a supermarket, surely everyone needs to shop too; for example, 
shopping for something that they needs. [As such we gather] with the crowd which is like in the [traditional] market that wow! [it] can't be avoided, ma'am." (Harry)

As a part of bigger system families are also involved in various social activities. Adult Balinese must attend various ceremonies hosted by their neighbors and relatives. During the event, the gathering is often inevitable.

"The most difficult thing to do is keep [a safe] distance... eh because in certain situations it is not [that we're] unwilling, sometimes it is not possible. I mean like yesterday there was a relative who died, so we held ngaben [cremation ceremony] in the cemetery. Because of the rain, eh everyone gathered at the wantilan [pavilion] that was inside the cemetery so keeping a safe distance was a bit difficult." (Aditia)

The family realized they should have not risked their and other's health, but they eventually compromised the measures. Went to the market for groceries and attended ceremonies were two situations that commonly caused compromisation.

\section{Theme 5: Intergenerational health attitudes}

Children and the elderly need more supervision in the implementation of protective measures within a family because they tend to be less vigilant. According to the participants, children and elderly needed to be constantly reminded in the implementation of protective measures.

"That's why the children too... it's hard [for them] to do this. They have to be reprimanded many times." (Hartini)

Some participants expressed their concerns about the neighbors' children who played outside and often did not adhere to protective measures.

"For the neighbors in this alley... not yet... Many people are not aware yet; for example, eh maybe because they are still young, right? There are also many kids who are elementary, junior high school age, like that. Those still play outside and are often without masks." (Harry)

Other than young members, the elderly also often forget to implement protective measures. Thus, other family members must remind them repeatedly.

"Father is already like that... usually wearing masks, [but] mother sometimes goes out forgetting to wear a mask. When she wears a mask, she wears it on her chin." (Lili)

Children and the elderly were family members who often overlook the protective measures, and this has the potential to increase transmission within the family. More attention and education should be given to these groups because they may jeopardize the health protocols that have been practiced by the other family members.

\section{Discussion}

In dealing with a pandemic and minimizing the COVID-19 transmission, families are the basic systems in society. They play a crucial role in implementing and promoting care and health behavior [25]. This research shows that families have carried out their functions in health care in terms of disease prevention to maintain the family members' health [26]. This study shows how families try to protect their members, but there are factors that influence the efforts and practices. As a result, the application of protective measures tend to be flexible and irregular.

The first theme of this study is the fundamental concerns, which is a form of awareness regarding the implementation of protective measures. Awareness of the threats posed by COVID-19 is demonstrated by the increasing attention to hygiene, by practicing health protocols such as wearing masks and reducing contact with other people [27]. Protecting families from contracting the COVID-19 virus is fundamental at this time of crisis. The function of promotion and prevention of disease can be seen when wearing mask and washing hands were the priority activities in the daily life of the family before other things. This is important information for health workers and policymakers in designing health promotion strategies to strengthen the implementation of protective measures. Maintaining public awareness to maintain protective behavior can be a challenge during this never-ending pandemic, therefore health promotion strategies must always consider various activities that become routine for families in everyday life.

It is important to note that families have assigned informal roles to their members, which is necessary for a more integrative and adaptive implementation [26]. The three roles revealed in this study seem to have helped family members to integrate actions. Families do have the tendency to form roles as a respond to certain situation [28], [29]; and this can be used as an important resource in developing strategies when working with families [29].

Factors from the family itself can also be a challenge. Children and elderly members often break the protocols. Children do not yet have adequate skills in adopting health behaviors, so they need to explore more of the surrounding environment and seek experiences to be able to change their behaviors [30], [31]. Although the number of COVID-19 cases among children is 
not as high as among adults, poor compliance on protective measures can increase the risk of them becoming carriers who will transmit the virus to other family members [32], [33]. Elderly family members are also in the age group who are less compliance with the protective measures, despite the fact that they are more vulnerable [34]. The limitation experienced by the elderly especially in accessing information that is rapidly changing, as well as the lack of ability to use various media [35] could be the reason behind their unawareness.

Children and the elderly are the age groups that require greater attention in the family. To increase awareness in implementing health protocols, interventions are needed that are in accordance with the growth and development characteristics of these family members. Publicity to raise awareness in implementing health-protective measures should be adapted to the cognitive capacity of these age groups. Messages for implementing health-protective measures can be made in the form of animations to attract children's attention because animation is one of the most important educational and socialization tools [36]. The elderly is less unlikely access updated information on digital media. Therefore, public messages on the use of health-protective measures should also be delivered on traditional media such as television and newspaper, as well as through their younger family members.

Restraints in the current study refer to the government's demand to reduce activities outside the house and to minimize interaction with other people. When restraints are imposed, a lot of family routines change so they have to adjust to the new conditions [37], [38], [39]. Constraints in adhering to the restraints will naturally arise, including when families try to implement the protective measures. Constraints are challenges faced by families to prevent the spread of COVID-19, and the most challenging for the families was keeping the safe distance from other people when they are outside. Maintaining distance and avoiding crowds were the biggest challenges for families, and subsequently they tend to compromise these two protective measures. Certain activities, especially those related to religion and customs, and providing foods and household supplies, push people to compromise protective measures implementation.

Preventing the spread of COVID-19 on a household level must be continued. Families as units in society will continue to adapt and struggle for the survival of each member. They are fully aware that the pandemic situation is a threat to every individual in the family. This can be seen from the main concern of the family in their daily activities during the pandemic which are to ensure that their members implement health protocols properly, to ensure that there are enough supplies such as masks and hand sanitizers, and to continue seeking information. However, more efforts are still needed to be able to capitalize on the potential. The challenges faced by families in implementing the prevention of COVID-19 come from within and outside of the family. To be able to maximize the potential of families in preventing COVID-19, support is needed to minimize the challenges.

One strategy to maximize the potential of families in implementing health protection measures properly is to implement a strict lockdown. A strict and broad lockdown strategy has been proven to reduce daily COVID-19 cases and cases requiring intensive care [40], [41], [42]. Strict lockdown is to reduce people's mobility as much as possible and close various non-essential industrial activities in large areas [40]. However, the policy to implement a strict and broad lockdown will certainly have an impact on the family economy and food security [43]. So the government also needs to consider interventions to maintain family resilience.

\section{Conclusion}

This paper shows that families place protective measures as a priority in their daily lives during the pandemic, but challenges remain. The positive side is that they are aware of the importance and they even assign informal roles to their members to integrate actions. The challenges include the disobedience of certain members such as children and the elderly and the normative responsibilities for families as a member of a community.

\section{References}

1. Walton M. Person and family-centred care. $\mathrm{Br} \mathrm{J}$ Nurs. 2014;23(17):949

PMid:25251178

2. SATGAS COVID-19. COVID-19 Map; 2020. p. 1. Available from: https://www.covid19.go.id/peta-sebaran. [Last accessed on 2020 Aug 03]

3. Bali Province. COVID-19 Map in Bali; 2020. Available from: https://www.pendataan.baliprov.go.id. [Last accessed on 2020 Sep 11].

4. SATGAS COVID 19. Must Know: Adapting to New Habits What You Need to Know? Task Force for the Acceleration of Handling COVID-19; 2020. Available from: https://www.covid19. go.id/edukasi/apa-yang-harus-kamu-ketahui-tentang-covid-19/ adaptasi-kebiasaan-baru. [Last accessed on 2020 Sep 11]. https://doi.org/10.31440/dftb.23868

5. Naidoo J. In: Wills J, editor. Foundations for Health Promotion $4^{\text {th }}$ ed. London : Elsevier; 2016.

6. Hanson CL, Crandall A, Barnes MD, Magnusson B, Novilla ML, 
King J. Family-focused public health: Supporting homes and families in policy and practice. Front Public Health. 2019;7:59. https://doi.org/10.3389/fpubh.2019.00059

\section{PMid:30949468}

7. Barnes MD, Hanson CL, Novilla LB, Magnusson BM, Crandall AC, Bradford G. Family-Centered Health Promotion: Perspectives for Engaging Families and Achieving Better Health Outcomes. Los Angeles, CA: SAGE Publications; 2020. https:// doi.org/10.1177/0046958020923537

8. Vedanthan R, Bansilal S, Soto AV, Kovacic JC, Latina J, Jaslow R, et al. Family-based approaches to cardiovascular health promotion. J Am Coll Cardiol. 2016;67(14):1725-37. https://doi.org/10.1016/j.jacc.2016.01.036

PMid:27056780

9. Gunn HE, Eberhardt KR. Family dynamics in sleep health and hypertension. Curr Hypertens Rep. 2019;21(5):39. https://doi. org/10.1007/s11906-019-0944-9 PMid:30982174

10. Mashabi S. When the Government admits it's wrong to Use "New Normal"; 2020. Available from: https://www.nasional. kompas.com/read/2020/07/14/05554601/saat-pemerintah-akuisalah-gunakan-diksi-new-normal?page=all. [Last accessed on 2021 May 28].

11. Trogen B, Caplan A. Risk compensation and COVID-19 vaccines. Ann Intern Med. 2021;174(6):858-9. https://doi. org/10.7326/m20-8251 PMid:33646837

12. Daly KJ. Qualitative Methods for Family Studies and Human Development. Los Angeles, CA: Sage Publications; 2007.

13. Gilgun JF, Daly K, Handel G. In: Gilgun JF, Daly K, Handel G, editors. Qualitative Methods in Family Research. Newbury Park London: Sage Publications; 1992. https://doi. org/10.2307/352829

14. Kahlke RM. Generic qualitative approaches: Pitfalls and benefits of methodological mixology. Int $J$ Qualitative Methods. 2014;13(1):37-52. https://doi. org/10.1177/160940691401300119

15. Tucker BP, Parker LD. Comparing Interview Interaction Modes in Management Accounting Research: A Case to Answer? AAA; 2015.

16. Farooq MB, de Villiers C. Telephonic Qualitative Research Interviews: When to Consider them and how to do them. Meditari Accountancy Research; 2017. https://doi.org/10.1108/ medar-10-2016-0083

17. Schober MF, Conrad FG, Antoun C, Ehlen P, Fail S, Hupp AL, et al. Precision and disclosure in text and voice interviews on smartphones. PLoS One. 2015;10(6):e0128337. https://doi. org/10.1371/journal.pone. 0128337

PMid:26060991

18. Dedoose. Dedoose Version 8.0.35, Web Application for Managing, Analyzing, and Presenting Qualitative and Mixed Method Research Data; 2018. Available from: http://www. dedoose.com. [Last accessed on $2021 \mathrm{Apr}$ 11].

19. Braun V, Clarke V. Using thematic analysis in psychology. Qual Res Psychol. 2006;3(2):77-101.

20. Byrne D. Research Ethics. Los Angeles, CA : SAGE Publications, Inc.; 2016.

21. Comstock G. Research Ethics: A Philosophical Guide to the Responsible Conduct of Research. Cambridge: Cambridge University Press; 2013.

22. Orb $A$, Eisenhauer $L$, Wynaden $D$. Ethics in qualitative research. J Nurs Scholarsh. 2001;33(1):93-6.

PMid:11253591

23. Silverman D. Doing qualitative research. $4^{\text {th }}$ ed. Los Angeles: SAGE; 2013.
24. Denzin NK, Lincoln YS. Strategies of Qualitative Inquiry. $4^{\text {th }}$ ed. Los Angeles, CA: SAGE; 2013.

25. The Ministry of Health R of I. Guidelines for Community Empowerment in Preventing Covid 19 in RT/RW/Village. The Ministry of Health; 2020.

26. Friedman MM, Bowden VR, Jones E. Family Nursing: Research, Theory and Practice. Hoboken, New Jersey: Prentice Hall; 2003.

27. Chen H, Xu W, Paris C, Reeson A, Li X. Social distance and SARS memory:Impactonthepublicawareness of 2019novelcoronavirus (COVID-19) outbreak. MedRxiv. 2020;2020:20033688. https:// doi.org/10.1101/2020.03.11.20033688

28. Dunphey DC. The Primary Group: A Handbook for Analysis and Field Research. New York: Appleton-Century-Crofts; 1972.

29. Quinn JR, Schmitt M, Baggs JG, Norton SA, Dombeck MT, Sellers CR. Family members' informal roles in end-of-life decision making in adult intensive care units. Am J Crit Care. 2012;21(1):43-51. https://doi.org/10.4037/ajcc2012520 PMid:22210699

30. Morrongiello BA, Midgett C, Shields R. Don't run with scissors: Young children's knowledge of home safety rules. J Pediatr Psychol. 2001;26(2):105-15. https://doi.org/10.1093/ jpepsy/26.2.105

PMid:11181886

31. Thomas AM, Peterson L, Goldstein D. Problem solving and diabetes Regiman adherence by children and adolescents with IDDM in social pressure situations: A reflection of normal development. J Pediatr Psychol. 1997;22(4):541-61. https://doi. org/10.1093/jpepsy/22.4.541

PMid:9302851

32. Bhopal SS, Bagaria J, Olabi B, Bhopal R. Children and young people remain at low risk of COVID-19 mortality. Lancet Child Adolesc Health. 2021;5(5):e12-3. https://doi.org/10.1016/ s2352-4642(21)00066-3

PMid:33713603

33. Saleem H, Rahman J, Aslam N, Murtazaliev S, Khan S. Coronavirus disease 2019 (COVID-19) in children: Vulnerable or spared? A systematic review. Cureus. 2020;12(5):e8207. https://doi.org/10.7759/cureus.8207 PMid:32577325

34. Liu K, Chen Y, Lin R, Han K. Clinical features of COVID-19 in elderly patients: A comparison with young and middle-aged patients. J Infect. 2020;80(6):e14-8. https://doi.org/10.1016/j. jinf.2020.03.005

PMid:32171866

35. Petretto DR, Pili R. Ageing and COVID-19: What is the Role for Elderly People? Basel, Switzerland: Multidisciplinary Digital Publishing Institute; 2020.

36. Kidenda MC. The necessity for parents to watch animated cartoons with children aged seven to eleven years. J Educ Pract. 2018;2(1):42-52. https://doi.org/10.47941/jep.261

37. Beck MJ, Hensher DA. Insights into the impact of COVID-19 on household travel and activities in Australia the early days under restrictions. Transp Policy. 2020;96:76-93. https://doi. org/10.1016/j.tranpol.2020.07.001

PMid:32834680

38. Chiesa V, Antony G, Wismar M, Rechel B. COVID-19 pandemic: Health impact of staying at home, social distancing and "lockdown" measures a systematic review of systematic reviews. J Public Health (Oxford, England). 2021;2021:fdab102. https://doi.org/10.1093/pubmed/fdab102

39. Narici M, de Vito G, Franchi M, Paoli A, Moro T, Marcolin G, et al. Impact of sedentarism due to the COVID-19 home confinement on neuromuscular, cardiovascular and metabolic health: Physiological and pathophysiological implications and 
recommendations for physical and nutritional countermeasures. Eur J Sport Sci. 2020;21(4):614-35. https://doi.org/10.1080/174 61391.2020 .1761076

PMid:32394816

40. Tobías A. Evaluation of the lockdowns for the SARS-CoV-2 epidemic in Italy and Spain after one month follow up. Sci Total Environ. 2020;725:138539. https://doi.org/10.1016/j. scitotenv.2020.138539

PMid:32304973

41. Zhao $\mathrm{S}$, Chen $\mathrm{H}$. Modeling the epidemic dynamics and control of COVID-19 outbreak in China. Quant Biol (Beijing, China).
2020;2020:1-9. https://doi.org/10.1101/2020.02.27.20028639 PMid:32219006

42. Amer F, Hammoud S, Farran B, Boncz I, Endrei D. Assessment of countries' preparedness and lockdown effectiveness in fighting COVID-19. Disaster Med Public Health Prep. 2021;15(2):e15-22. https://doi.org/10.1017/dmp.2020.217 PMid:32576332

43. Ceballos F, Kannan S, Kramer B. Impacts of a national lockdown on smallholder farmers' income and food security: Empirical evidence from two states in India. World Dev. 2020;136:105069. https://doi.org/10.1016/j.worlddev.2020.105069 